\title{
Synthesis of functionalized biaryls using iminophosphorane palladacycles as Suzuki catalysts
}

Adolfo Fernández-Figueiras',* , Fátima Lucio-Martínez¹, Paula Munín¹, Francisco Reigosa1, José M. Vila' ${ }^{1}$ M. Teresa Pereira ${ }^{1}$, Paula Polo-Ces ${ }^{1}$

1 Departamento de Química Inorgánica, Facultad de Química, Campus Vida, Universidade de Santiago de Compostela, adolfo.fernndez@rai.usc.es, fatimaluciomartinez@gmail.com, paula.munin@usc.es, francisco.reigosa@rai.usc.es, josemanuel.vila@usc.es, mteresa.pereira@usc.es, paulamaria.polo@usc.es

* Correspondence: adolfo.fernndez@rai.usc.es ; Tel.: +34-881-814-442

$+21^{\text {st }}$ International Electronic Conference on Synthetic Organic Chemistry, 1-30 november 2017.

Academic Editor: name

Received: date; Accepted: date; Published: date

\begin{abstract}
The Suzuki-Miyaura cross coupling reaction is a very powerful tool for making of C-C bonds from organic halides and organoboron compounds [1]. This reaction, for which palladacycles have shown great catalytic activity [2] is widely employed in academic laboratories as well as in pharmaceutical industries to synthesize organic compounds or drugs such as Losartan [3], an antihypertensive medicine.

Iminophosphoranes are organic compounds of general composition $\mathrm{R}_{3} \mathrm{P}=\mathrm{NR}$ and can be used as in coordination and in organometallic chemistry [4]. The aim of this work is to study the catalytic activity of new palladium organometallic compounds derived from iminophosphorane ligands.
\end{abstract}

Keywords: Iminophosphorane, catalysis, Suzuki, palladacycle, organometallic

\section{Introduction}

Cross-coupling reactions have been widely used in organic synthesis as well as in the chemical industry. One of the most usual is the Suzuki catalysis, which allows formation of C-C bonds between two aryls by reaction of an organic halide and an organoboron compound. To perform the reaction a catalyst is needed, generally a palladium compound. In 1989, Hermann et al. showed that palladium cyclometallated compounds could behave as excellent catalysts for this reaction [2].

Iminophosphoranes are ligands in coordinated compounds as well as in cyclometallated compounds with many metals, especially $\mathrm{Au}$ [5], Pd [6] and Pt [7], which have luminescent and anti-cancer properties. For these reasons, we have considered important to approach the synthesis of new palladium (II) cyclometallated compounds derived from iminophosphoranes and to consider their properties as Suzuki catalysts.

\section{Methods}

2-(methylthio)aniline iminophosphoranes may behave as tridentante ligands, which may be easily obtained by the Staudinger reaction as depicted in Scheme 1.
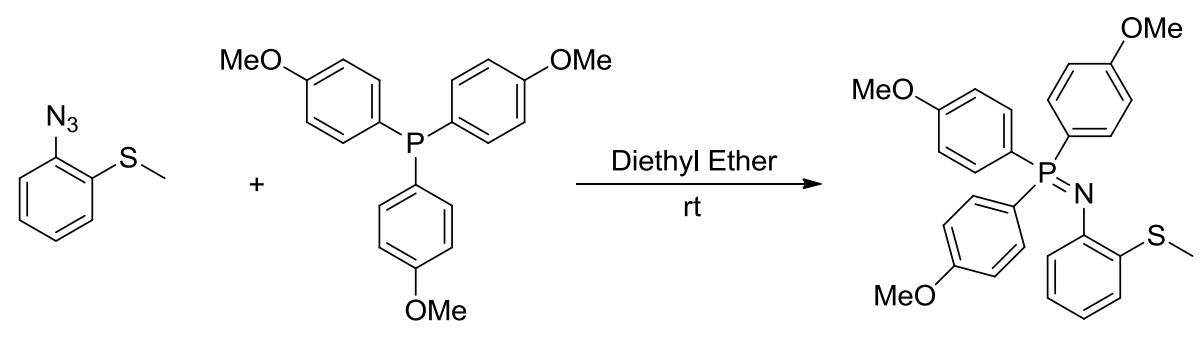

Scheme 1: Staudinger reaction 
Compound 2 may be obtained by the reaction of a palladium salt with the iminophosphorane ligand (Scheme 2). The presence of a base is not necessary but facilitates the cyclometallation reaction and prevents de formation of the $[\mathrm{N}, \mathrm{S}]$ coordination compound.
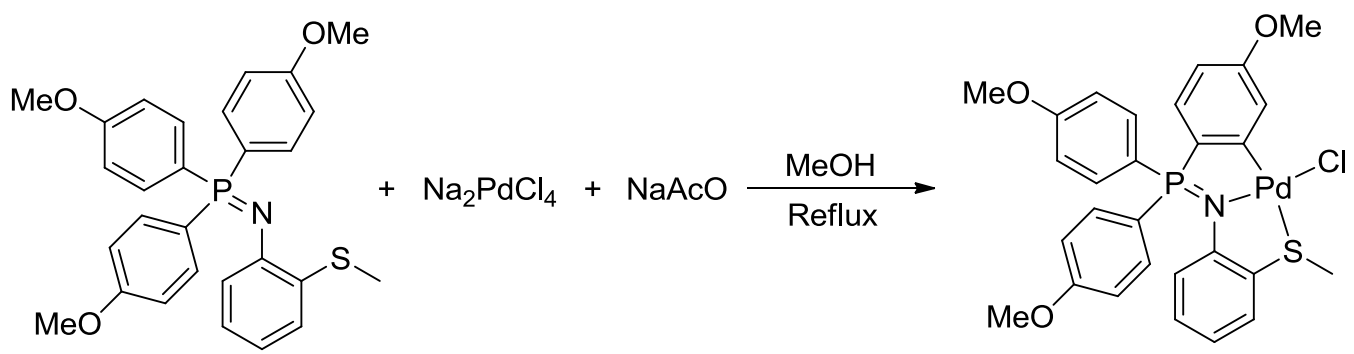

Scheme 2: Formation of the cyclometallated compound

Compound 2 is an air-stable bright yellow solid. The metal atom shows a square-planar geometry and has two covalent bonds with nitrogen and sulfur atoms and one $\sigma$ bond with the carbon atom.

\section{Results and discussion}

\subsection{Synthesis of 2-(methylthio)phenylazide}

To a mixture of 2-(methylthio)aniline $(1000 \mathrm{mg}, 7.183 \mathrm{mmol})$, in water $\left(1.5 \mathrm{~cm}^{3}\right)$, ethyl acetate $(7$ $\left.\mathrm{cm}^{3}\right)$ and $\mathrm{HCl} 37 \%\left(1.5 \mathrm{~cm}^{3}\right)$ was added dropwise sodium nitrite $(843 \mathrm{mg}, 12.211 \mathrm{mmol})$ in water under vigorous stirring at $0-5{ }^{\circ} \mathrm{C}$. After $30 \mathrm{~min}$ aqueous NaN3 (793 mg, $12.211 \mathrm{mmol}$ ) was added dropwise to the reaction mixture at $0-5^{\circ} \mathrm{C}$ for 30 minutes. The mixture was extracted with ethyl acetate and washed with water. The organic layer was evaporated and a pale yellow powder was obtained. Yield $1021 \mathrm{mg}(86 \%)$.

\subsection{Synthesis of the compound 1}

To a solution of 2-(methylthio)phenylazide ( $300 \mathrm{mg}, 1.816 \mathrm{mmol})$ in diethyl ether $\left(15 \mathrm{~cm}^{3}\right)$ was added tris(4-methoxyphenyl)phosphine $(640 \mathrm{mg}, 1.816 \mathrm{mmol})$ and stirred at room temperature for two hours. The solvent of the resulting solution was evaporated to dryness giving a yellow powder. Yield $752 \mathrm{mg}$ (83.1 \%). Anal. Calc. for $\mathrm{C}_{28} \mathrm{H}_{28} \mathrm{NO}_{3} \mathrm{PS}$ : C, 68.7; $\mathrm{H}, 5.8 ; \mathrm{N}, 2.7 ; \mathrm{S}, 6.6$. Found: $\mathrm{C}, 68.8 ; \mathrm{H}$, 5.9; N, 2.6; S, 6.5. ${ }^{1} \mathrm{H} \mathrm{NMR}\left(\mathrm{CDCl}_{3}\right): \delta=2.35\left(\mathrm{~s} 3 \mathrm{H}, \mathrm{CH}_{3} \mathrm{~S}\right) \quad 3.74\left(\mathrm{~s} 9 \mathrm{H}, \mathrm{CH}_{3} \mathrm{O}\right) 6.35(\mathrm{~m}, 1 \mathrm{H}, \mathrm{H} 4) 6.63(\mathrm{~m}$

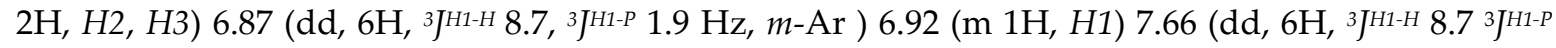
$11.5 \mathrm{~Hz}, o-\mathrm{Ar}){ }^{31} \mathrm{P}\left\{{ }^{1} \mathrm{H}\right\} \mathrm{NMR}\left(\mathrm{CDCl}_{3}\right): \delta=-0.14(\mathrm{~s})$.

\subsection{Synthesis of the compound 2}

To a mixture of [Na2PdCl4] (75 mg, 0,255 mmol), NaOAc (19 mg, 0,255 mmol,) and compound 1 $(125 \mathrm{mg}, 0,255 \mathrm{mmol})$ was added methanol $(10 \mathrm{~cm} 3)$ and heated to $80^{\circ} \mathrm{C}$ for 18 hours. The resulting solution was evaporated, the solid obtained was dissolved in dichloromethane and filtered through silica, after which the solvent was removed under vacuum and a yellow bright powder was obtained. Yield $116 \mathrm{mg}$ (72.0 \%). Anal. Calc. for $\mathrm{C}_{28} \mathrm{H}_{27} \mathrm{ClNO}_{3} \mathrm{PPdS}$ : C, 53.3; H, 4.3; N, 2.2; S, 5.1 . Found: $\mathrm{C}, 53.4 ; \mathrm{H}, 4.5 ; \mathrm{N}, 2.2 ; \mathrm{S}, 5.0 .{ }^{1} \mathrm{H} \mathrm{NMR}\left(\mathrm{CDCl}_{3}\right): \delta=2.76\left(\mathrm{~s}, 3 \mathrm{H}, \mathrm{CH}_{3} \mathrm{~S}\right) 3.85\left(\mathrm{~s}, 6 \mathrm{H}, \mathrm{CH}_{3} \mathrm{O}\right) 3.86(\mathrm{~s}$, $\left.\left.3 \mathrm{H}, \mathrm{CH}_{3} \mathrm{O}\right) 6.59(\mathrm{~m}, 1 \mathrm{H}, \mathrm{H7}) 6.64\left(\mathrm{~d}, 1 \mathrm{H}{ }^{3}\right)^{\mathrm{H}-\mathrm{H}} 8.4 \mathrm{~Hz}, \mathrm{H1}\right) 6.71(\mathrm{~m}, 2 \mathrm{H}, \mathrm{H} 2, \mathrm{H} 6) 6.86(\mathrm{~m}, 1 \mathrm{H}, \mathrm{H} 3) 7.01$

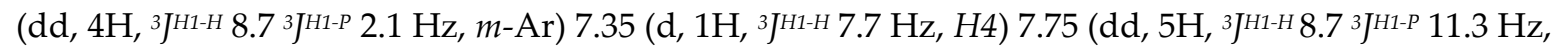
o-Ar, H5), ${ }^{31} \mathrm{P}\left\{{ }^{1} \mathrm{H}\right\} \mathrm{NMR}\left(\mathrm{CDCl}_{3}\right): \delta=44.63$ (s).

\subsection{Characterization}

The compounds were characterized by ${ }^{1} \mathrm{H}$ and ${ }^{31} \mathrm{P}\left\{{ }^{1} \mathrm{H}\right\}$ NMR spectroscopy. 
The ${ }^{1} \mathrm{H}$ NMR shows the formation of the iminophosphorane 1 , the three phenyl rings bonded to phosphorus are chemically equivalent (Figure 1).

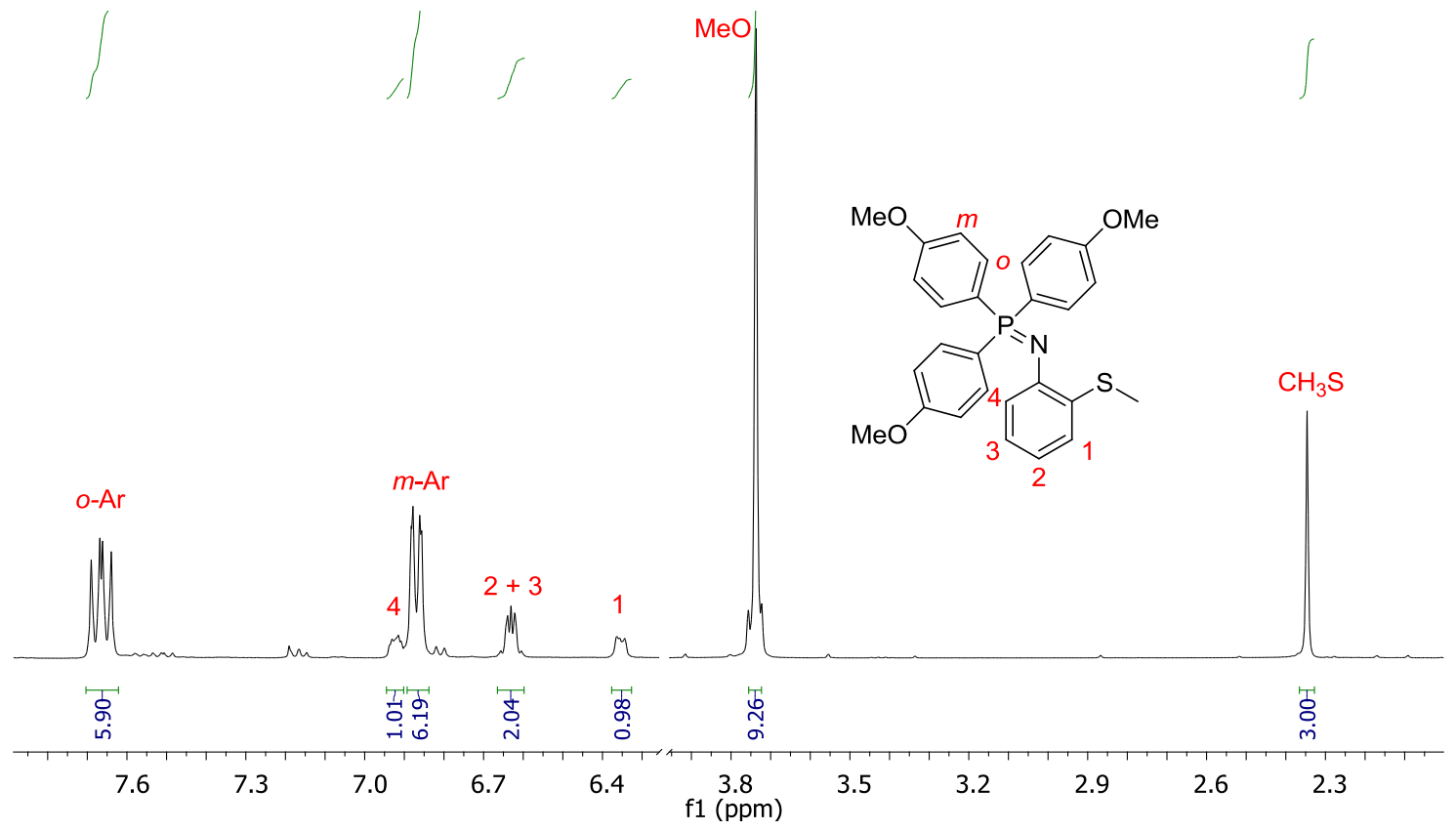

Figure $1 .{ }^{1} \mathrm{H}$ NMR spectrum for 1

In compound 2, only two of the three phenyl rings bonded to the phosphorus atom are chemically equivalent, the other ring shows different signals after metallation by palladium (Figure 2).

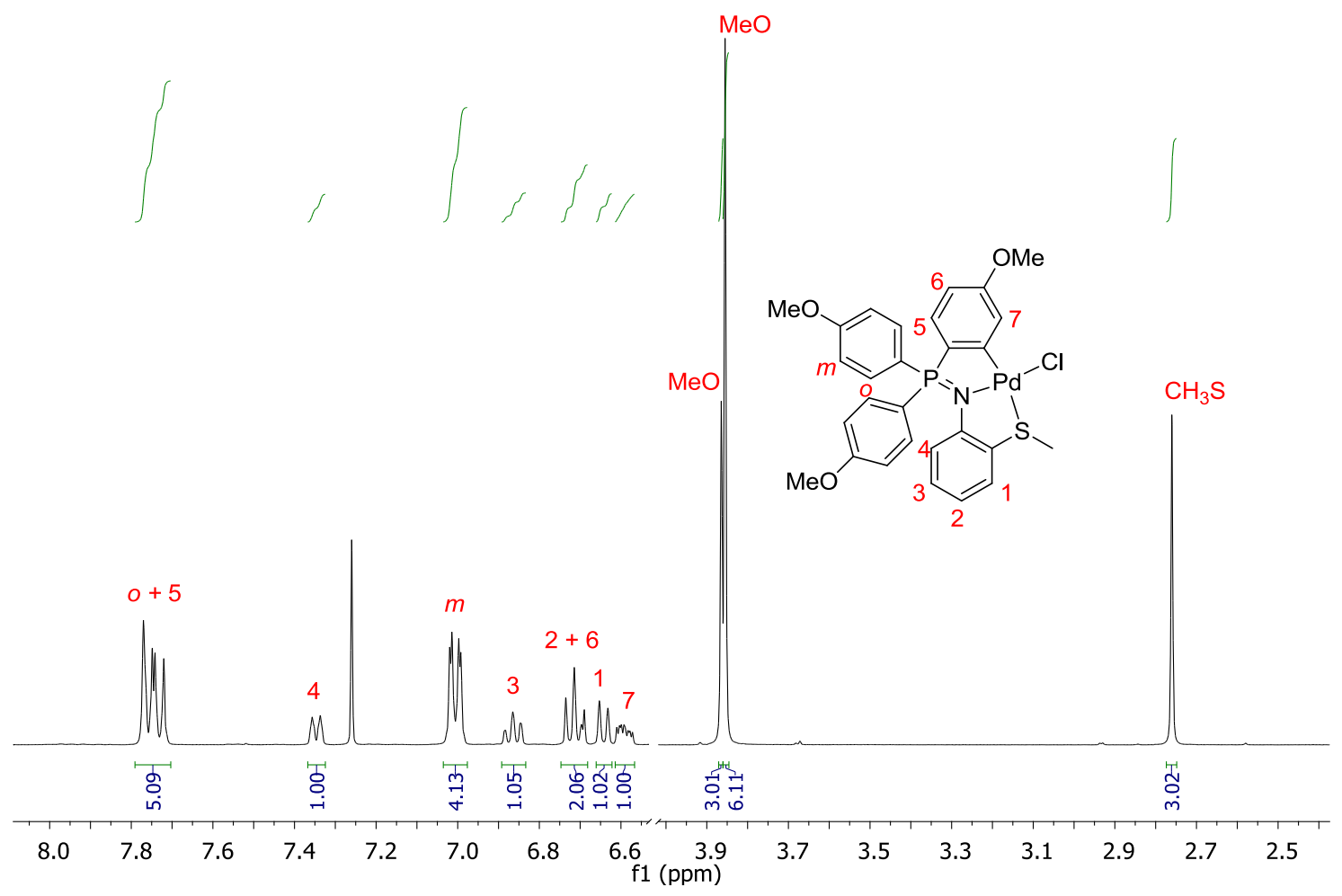

Figure 2. ${ }^{1} \mathrm{H}$ NMR spectrum for 2

Comparison of the ${ }^{31} \mathrm{P}\left\{{ }^{1} \mathrm{H}\right\}$ spectra of compounds $\mathbf{1}$ and $\mathbf{2}$ clearly shows a shift of the signal assigned to the phosphorus nucleus (Figure 3). 


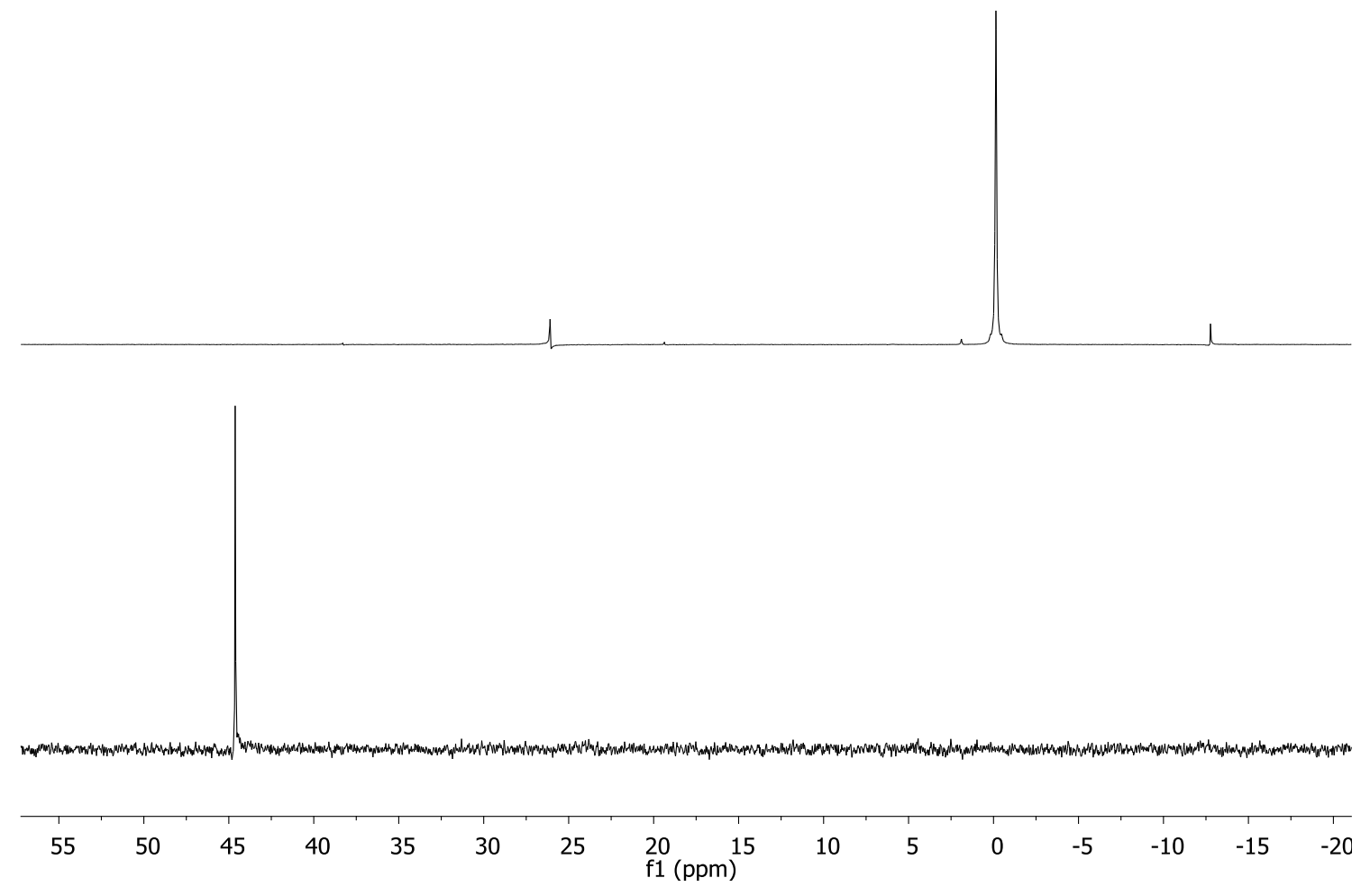

Figure 3. ${ }^{31} \mathrm{P}\left\{{ }^{1} \mathrm{H}\right\}$ spectrum for $\mathbf{1}$ (above) and $\mathbf{2}$ (bottom)

Crystals of compound 2 where obtained by slow evaporation from a chloroform solution. The X-ray diffraction study confirms the formation of the cyclometallated compound as is shown in Figure 4.

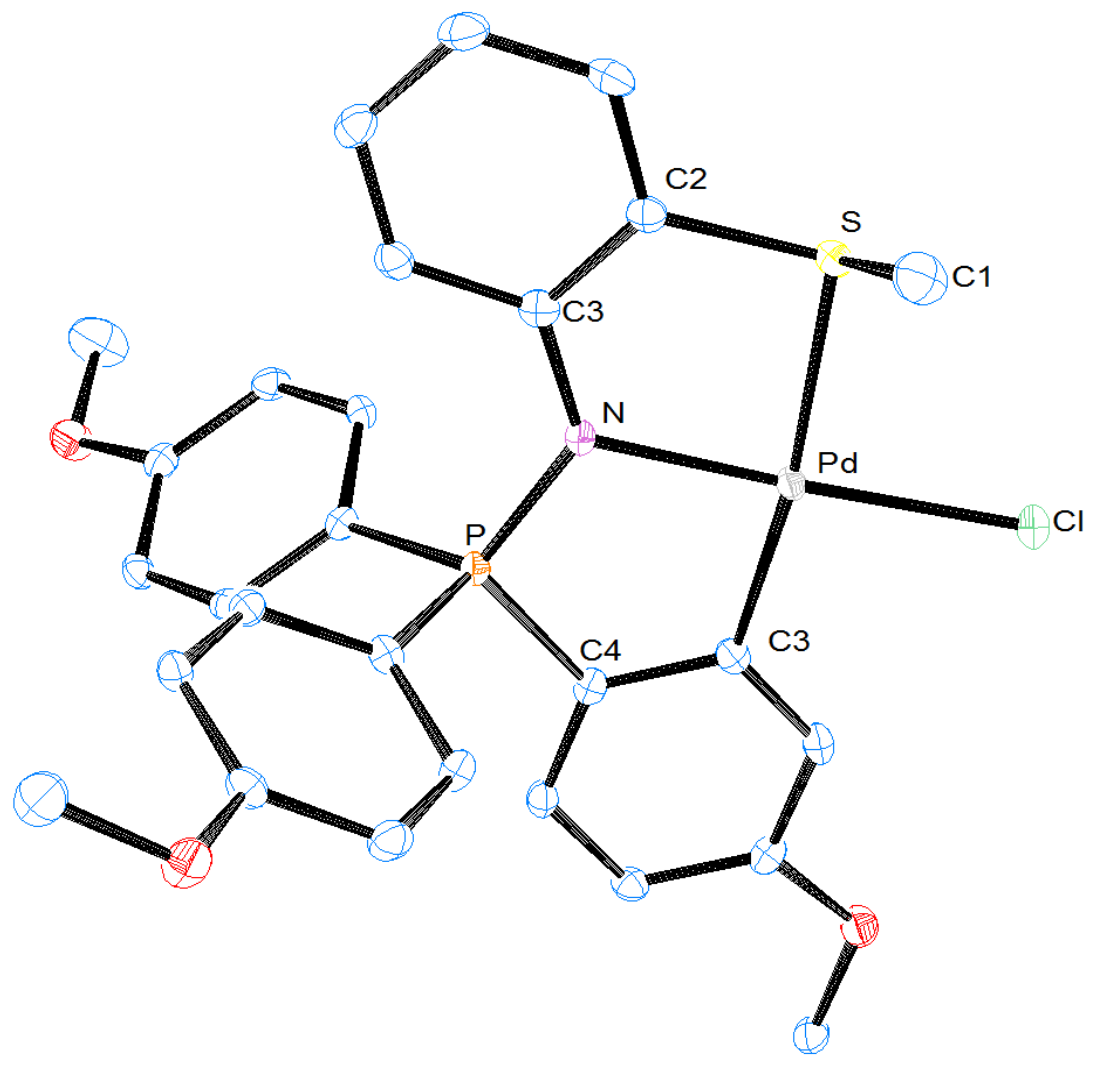

Figure 4 . Structure of $\mathbf{2}$, hydrogen atoms are omitted 
Crystal data is shown in Table 1.

\begin{tabular}{cc}
\hline Empirical formula & $\mathrm{C}_{28} \mathrm{H}_{27} \mathrm{ClNO}_{3} \mathbf{P P d S}$ \\
\hline Molecular weight & 630.39 \\
Temperature & $100.0(1) \mathrm{K}$ \\
Wavelength & $0.71073 \AA$ \\
Crystal system & Orthorhombic \\
Space group & $\mathrm{P} 2(1) 2(1) 2(1)$ \\
& $\mathrm{a}=12.223(5) \AA \quad \alpha=90.000(5)^{\circ}$ \\
Unit cell dimensions & $\mathrm{b}=13.996(5) \AA \quad \beta=90.000(5)^{\circ}$ \\
& $\mathrm{c}=15.093(5) \AA \quad \gamma=90.000(5)^{\circ}$ \\
Volume & $2582.0(16) \AA^{3}$ \\
$\mathrm{Z}$ & 4 \\
Calculated density & $1.622 \mathrm{Mg} / \mathrm{m}^{3}$ \\
Absorption coefficient & $0.997 \mathrm{~mm} \mathrm{~m}^{-1}$ \\
F(000) & 1280 \\
Crystal size & $0.42 \times 0.36 \times 0.20 \mathrm{~mm}$ \\
range for data collection & $1.98-30.50^{\circ}$ \\
Index ranges & $-17<=\mathrm{h}<=17,-19<=\mathrm{k}<=18,-21<=1<=19$ \\
Reflections collected/independent & $59539 / 7893\left[\mathrm{Rint}^{\circ}=0.0586\right]$ \\
Data/restraints/parameters & $7893 / 0 / 325$ \\
Goodness-of-fit on $\mathrm{F}^{2}$ & 1.032 \\
Final R indices [I $2 \sigma(\mathrm{I})]$ & $\mathrm{R}_{1}=0.0287, \mathrm{wR}=0.0583$ \\
$\mathrm{R}$ índices (all data) & $\mathrm{R}_{1}=0.0322, \mathrm{wR} \mathrm{R}_{2}=0.0594$ \\
\hline
\end{tabular}

Table 1. Crystal data

\subsection{Catalysis}

The cross-coupling reaction between 4-bromoacetophenone and phenylboronic acid was studied using a $2 \% \mathrm{M}$ compound $\mathbf{2}$ as catalyst. The reaction was carried out in ethanol, using an excess of $\mathrm{K}_{3} \mathrm{PO}_{4}$ as base (Scheme 3 ).

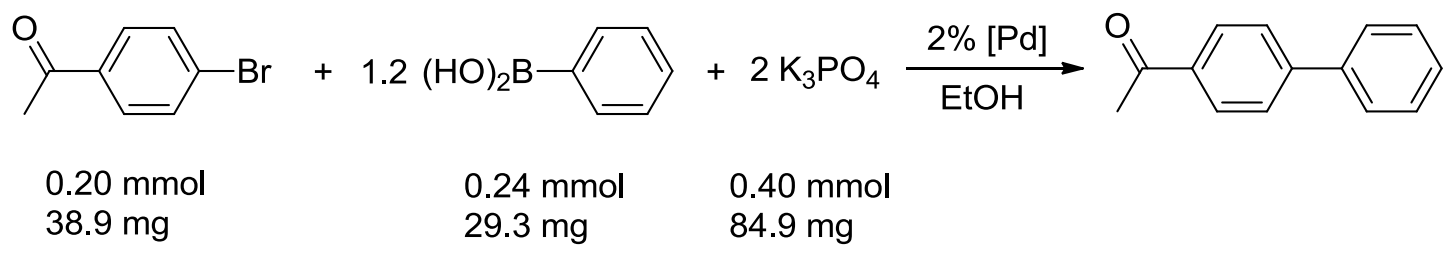

Scheme 3. Catalysis reaction

The yield of the reaction was measured by ${ }^{1} \mathrm{H}$ NMR spectroscopy (Table 2).

\begin{tabular}{ccc}
\hline Temperature $/{ }^{\circ} \mathbf{C}$ & Time/ $\mathbf{h}$ & Yield $/ \%$ \\
\hline \multirow{2}{*}{50} & 1 & 51 \\
& 4 & 91 \\
80 & 6 & 100 \\
& 1 & 100 \\
\hline
\end{tabular}

Table 2: Catalysis results 


\section{Conclusions}

A new palladacycle derived from an iminophosphorane ligand has been synthesized and characterized. This compound shows good catalytic activity in the Suzuki-Miyaura reaction even at relatively low temperatures.

Acknowledgments: We wish to thank the financial support received from the Xunta de Galicia (Galicia, Spain) under the Grupos de Referencia Competitiva Programme Projects GRC2015/009. F. Lucio-Martínez and F. Reigosa thank the Spanish Ministry of Education (grant FPU13/05014 and FPU15/07145).

Conflicts of Interest: the authors declare no conflict of interest.

\section{References}

1. Miyaura, N.; Yamada, K.; Suzuki, A. A new stereospecific cross-coupling by the palladium-catalyzed reaction of 1-alkenylboranes with 1-alkenyl or 1-alkynyl halides. Tetrahedron Letters, 1979, 20, 3437, 10.1016/S0040-4039(01)95429-2

2. Herrmann, W. A.; Brobmer, C.; Öfele, K.; Reisinger, C.-P.; Priermeier, T.; Beller, M.; Fischer, H. Palladacycles as Structurally Defined Catalysts for the Heck Olefination of Chloro- and Bromoarenes. Angew. Chem., 1995, 107, 1989, 10.1002/anie.199518441.

3. Smith, G. B.; Dezeny, G. C.; Hughes, D. L.; King, A. O.; Verhoeven, T. R. Mechanistic studies of the Suzuki cross-coupling reaction. J. Org. Chem. 1994, 59, 8151, 10.1021/jo00105a036.

4. Wei, P.; Chan, K. T. K; Stephan, D. W. Metallated triphenylphosphinimine complexes. Dalton Trans., 2003, 3804, 10.1039/B305877H.

5. Frik, M.; Fernández-Gallardo, J.; Gonzalo, O.; Mangas-Sanjuan, V.; González-Alvarez, M.; Serrano del Valle, A.; Hu, C.; González-Alvarez, I.; Bermejo, M.; Marzo, I.; Contel, M. Cyclometalated Iminophosphorane Gold(III) and Platinum(II) Complexes. A Highly Permeable Cationic Platinum(II) Compound with Promising Anticancer Properties. J. Med. Chem., 2015, 58, 5825, 10.1021/acs.jmedchem.5b00427.

6. Bielsa, R.; Larrea, A.; Navarro, R.; Soler, T.; Urriolabeitia, E. P. Synthesis, Structure, Reactivity, and

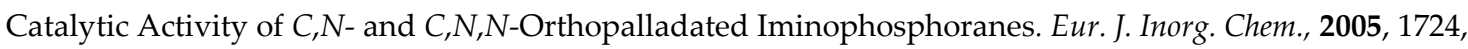
10.1002/ejic.200400907.

7. Frik, M.; Jiménez, J.; Vasilevski, V.; Carreira, M.; de Almeida, A.; Gascón, E.; Benoit F.; Sanaú, M.; Casini, A.; Contel, M. Luminescent iminophosphorane gold, palladium and platinum complexes as potential anticancer agents. Inorg. Chem. Front., 2014, 1, 231, 10.1039/C4QI00003I.

(c) 2017 by the authors. Submitted for possible open access publication under the terms and conditions of the Creative Commons Attribution (CC BY) license (http://creativecommons.org/licenses/by/4.0/). 